\title{
Analysis of The Effect of Financial Literation, Financial Technology, Income, and Locus of Control on Lecturer Financial Behavior
}

\author{
Wahyudi ${ }^{1 *}$, Brigitta Azalea Pulo Tukan ${ }^{2}$, and Dahlia br. Pinem ${ }^{3}$ \\ 1, 2, ${ }^{3}$ Universitas Pembangunan Nasional Veteran Jakarta, Jakarta, Indonesia
}

\begin{abstract}
This research is a quantitative study that aims to determine the effect of financial literacy, financial technology, income, and locus of control on financial behavior. The population in this study were Lecturers at the Universitas Pembangunan Nasional Veteran Jakarta. The sample size was taken as many as 80 respondents, with methods through nonprobability sampling, purposive sampling. Data collection was carried out through questionnaires. The analysis technique used is the PLS (Partial Least Square) analysis method with SmartPLS 3.0 software. The results of this study indicate that (1) financial literacy has a significant positive effect on financial behavior. (2) financial technology has no influence and is not significant in financial behavior. (3) income has a significant positive effect on financial behavior. (4) locus of control does not influence financial behavior.
\end{abstract}

Keywords: Financial Behavior, Financial Literacy, Financial Technology, Income, Locus of Control.

\section{Introduction}

The development of the financial world today gives people many choices in making financial decisions. A variety of new and varied financial products require people to understand them more deeply if they want to use them. This is necessary to avoid making bad financial decisions or in other words, poor financial behavior. Individual finance can be managed well if the financial behavior of the individual is responsible. Financial behavior is one issue that is widely discussed today. This has an impact on the many phenomena that arise in Indonesian society regarding poor financial management. So to minimize unfavorable financial behavior, every individual must have an understanding of good finance so that they can avoid financial problems that might occur.

An understanding of finance can also be referred to as financial literacy. Financial literacy is the level of knowledge, skills, beliefs that influence attitudes and behaviors to improve the quality of decision making, and financial management to prosper (Otoritas Jasa Keuangan, 2016). Based on research conducted by (Anggraeni and Tandika, 2019) and (Mien and Thao, 2015) stated that financial literacy and financial knowledge influence financial behavior. While the research conducted by (Herdjiono and Damanik, 2016) states that the financial knowledge one does not influence the financial behavior of the person.

Bank Indonesia Regulation Number 19/12/PBI/2017, FinTech is "the use of financial system technology that produces new products, services, technology and/or business models and can have an impact on monetary stability, financial system stability, efficiency, smoothness, security, and payment system reliability. "Fintech is an innovation that provides convenience and comfort for people in the financial sector because people can make transactions only with smartphones and the internet. The presence of fintech has a positive impact on improving the economy because of the continued growth in volume and value of shopping transactions. However, behind the

* Corresponding author. Email address: upnvj.wahyudi@gmail.com 
positive side, the culture of online shopping and cashless raises the problem of consumerism which can affect one's financial behavior.

Income received by someone should be directly proportional to the financial behavior of that person. Because someone who has a higher income is likely to behave well financially because the available funds allow them to act more responsibly (Purwidianti and Mudjiyanti, 2016). While someone who has a low income, will have the opportunity to act responsibly because they have limited funds, not infrequently the income they have is only enough to meet their daily needs, so they do not have the opportunity to save or invest. Based on research conducted by (Andrew and Linawati, 2014) states that income affects financial behavior. While research conducted by (Purwidianti and Mudjiyanti, 2016) states that the level of income does not affect financial behavior.

Financial behavior can be influenced by several factors, which is locus of control. Based on research conducted by (Alexander and Pamungkas, 2019) revealed that locus of control has a significant positive effect on financial behavior. Whereas research conducted by (Ida and Dwinta, 2010) states that locus of control has a negative relationship with financial behavior.

Based on the above problems, the problem formulation in this study is as follows:

a. Does financial literacy affect the financial behavior of the Lecturer at the Faculty of Economics and Business UPN Veteran Jakarta?

b. Does financial technology affect the financial behavior of the Lecturer at the Faculty of Economics and Business UPN Veteran Jakarta?

c. Does income affect the financial behavior of the Lecturer at the Faculty of Economics and Business UPN Veteran Jakarta?

d. Does locus of control affect the financial behavior of the Lecturer at the Faculty of Economics and Business UPN Veteran Jakarta?

So the purpose of this research is to find out and analyze how much the influence of financial literacy, financial technology, income, and locus of control on the financial behavior of the Lecturer at the Faculty of Economics and Business UPN Veteran Jakarta.

\section{Literature Review}

\subsection{Financial Behavior}

Financial behavior (financial behavior) emerged in the 1990s in line with the demands of the development of business and academic world that began to address the aspects or elements of behavior in the process of making financial and investment decisions. Behavioral finance explains how people treat, manage, and use financial resources owned (Suryanto, 2017). A person who has good financial behavior will be in charge of his finances and can be seen through the way that person uses money by budgeting, saving money and controlling expenses, making investments, and paying debts on time. Financial behavior is the result of putting expectations and values into action, with the expectation that financial behavior will mediate the relationship of expectations on financial well-being (Burcher et al, 2018). Financial management behavior is related to a person's financial responsibilities regarding how to manage their finances (Purwidianti and Mudjiyanti, 2016). The process of financial management and other assets that are owned productively can be said as financial responsibility. This also relates to the process of mastering the use of financial assets. Several elements are included in effective money management, such as budgeting, assessing the need for purchases, and pension debt in a reasonable time frame (Purwidianti and Mudjiyanti, 2016). 


\subsection{Financial Literacy}

Financial literacy or better known as knowledge in financial regulation is one of the economic behaviors that develop in a society that has consciously or not been carried out for a long time. Based on the Otoritas Jasa Keuangan 76/POJK.07/2016 on Increasing Financial Literacy and Inclusion in the Financial Services Sector for Consumers and/or Communities, "financial literacy is knowledge, skills, beliefs, which influence attitudes and behaviors to improve the quality of decision making and financial management to prosper." A person's level of financial literacy can be divided into four types of levels ranging from best to worst, namely Well Literate, Suff Literate, Less Literate, and Not Literate. Well Literate indicates that someone already has knowledge, confidence, and is skilled in using financial products and services. Suff Literate indicates that someone already has knowledge and confidence in financial institutions, products, and services, but is not yet skilled in using it. Less Literate indicates that someone only knows financial institutions, products, and services. Whereas Not Literate indicates that a person does not have knowledge and beliefs about financial institutions, products and services, and is not skilled in using them.

\subsection{Financial Technology}

Fintech comes from the term financial technology. Financial technology according to Bank Indonesia Reagulation 19/12/PBI/2017 is "the use of financial system technology that produces new products, services, technology and/or business models and can have an impact on monetary stability, financial system stability, efficiency, smoothness, security, and payment system reliability".

Bank Indonesia (2016) classifies financial technology into four categories, as follows:

a. Crowdfunding and peer-to-peer (P2P) lending

This category is a means of meeting between investors and capital seekers. This platform uses information technology, especially the internet, to provide easy loan services. Capital providers only provide capital and the borrower makes the loan process through an online platform.

b. Market Aggregator

This category is a medium that collects and collects financial data from various data providers to be presented to users. This financial data can then be used to facilitate users in comparing and choosing the best financial products.

c. Risk and Investment Management

The following categories are classifications for financial technology services that function as financial planners in digital form. So users can plan and know the financial condition at any time and all circumstances.

d. Payment, Settlement, and Clearing

Financial technology services in this category serve to facilitate users in making payments online quickly. In 2016, Bank Indonesia issued Bank Indonesia Regulation 18/40/PBI/2016 concerning Processing of Payment Transactions. This regulation aims to continue to support the creation of a smooth, safe, efficient and reliable payment system by prioritizing the fulfillment of prudential principles and adequate risk management and by taking into account the expansion of access, national interests, and consumer protection, including standards, and international practices.

\subsection{Income}

Gross income is all revenue obtained from all branches in each business (Subandriyo, 2016). Then, personal income is personal income before tax (Purwidianti and Mudjiyanti, 2016). The biggest component of total income is wages and salaries. Also, there are many other categories of income, including rental income, interest income, and dividend income. Often salaries or wages are considered to have the same meaning, but in real wages and salaries have different meanings (Larasati, 2018). 
Salary is usually said as wages given to the leadership, supervisors, and administration of office employees or other management. Salaries are generally higher than payments to wage workers. Whereas wages are payments to workers or employees paid based on the length of time they worked. namely :

According to Simamora (in Larasati, 2018) compensation divided into three,

a. Direct Financial Compensation

This compensation consists of fees that someone gets in the form of salary, wages, bonuses, or commissions.

b. Indirect Financial Compensation

This compensation is also referred to as benefits, covering all financial rewards that are not covered by direct compensation.

c. Nonfinancial Compensation

This compensation consists of satisfaction obtained by someone from the work itself or from the psychological and physical environment in which the person works.

\subsection{Locus of Control}

Locus of control according to (Pradiningtyas and Lukiastuti, 2019), is the attitude of someone who believes that what happens in him is a result of his actions. (Yusnia and Jubaedah, 2017) said that "the locus of control is where a person can control himself or can not control himself to determine his destiny in situations that occur to oneself or the environment." Meanwhile, according to Wibowo (2013), locus of control is a belief that an individual has about the amount of control they have over the events of personal life. Locus of control is divided into two categories, internal and external. Individuals with an internal locus of control have the point of view that all the results obtained are good or bad due to factors from within themselves such as ability, skills, and effort. Individuals who have an internal locus of control also have a high work ethic, enduring various kinds of difficulties both in their lives and in their work. While individuals who have an external locus of control have a perspective where all the results obtained are good or bad outside their control caused by various external factors such as luck, opportunity, and destiny. Individuals with an external locus of control will assume that the problems that come as a threat to themselves. If someone has a failure or can not solve a problem, then the individual will consider a failure is a fate that is owned and causes himself to want to run away from the problem. Some people think that effort and ability are factors that can influence a person to achieve success, but some other people also have the idea that factors outside their control can lead them to success including luck, opportunity, fate, and destiny (Amalini et al., 2016).

\subsection{Hypothesis}

Based on the literature review above, the hypotheses in this study are:

$\mathrm{H}_{1}$ : Financial literacy affect financial behavior.

$\mathrm{H}_{2}$ : Financial technology affect financial behavior.

$\mathrm{H}_{3}$ : Income affect financial behavior.

$\mathrm{H}_{4}$ : Locus of control affect financial behavior.

\section{Research Methodology}

This study used the Lecturers of the Faculty of Economics and Business UPN Veteran Jakarta with 80 respondents as research objects so that the research location was in the area of the UPN Veteran Jakarta.

This study uses three independent variables and one dependent variable. The variables in this study consisted of: 
a. Financial literacy is a person's ability to make effective decisions related to finance to improve financial welfare. In this study, financial literacy is an independent variable that has a score obtained from respondents' answers using a Likert scale seen from several indicators namely personal financial knowledge, savings and loans, investment, and insurance.

b. Financial Technology, is an innovation in the field of financial services that utilize technological developments. Fintech is classified into several categories such as payments, investments, loans, and others. In this study, fintech is an independent variable that has a score obtained from respondents' answers using a Likert scale seen from several indicators, namely an understanding of financial technology, knowledge, and understanding of financial technology products, and the use of financial technology.

c. Income is the level of monthly income obtained by respondents. In this study, income is an independent variable that has a score obtained from respondents' answers using a Likert scale seen from the indicator that is financial income consisting of salary/wages and bonus/commission.

d. Financial behavior is a person's attitude in managing and using financial resources that are owned. Financial behavior has a score obtained from respondents' responses to financial behavior using a Likert scale of indicators that is paying bills on time, making expenditure budgets, making financial records, providing funds for unexpected expenses, saving regularly, investing a portion of income, and comparing prices before deciding on a purchase.

e. Locus of Control is the level of confidence held by individuals in controlling themselves both from internal and external control over the causes of events that occur in their lives. Locus of control has a score obtained from respondents' answers to the locus of control using a Likert scale of indicators, namely the potential for behavior, expectations, the value of reinforcing elements, and the psychological atmosphere.

In this study, researchers used SmartPLS 3.0 software to analyze data. Test the quality of data in this research is how to test the validity and reliability of the data that has been collected from questionnaires filled out by respondents. The validity test is measured using Fornell Lacker-Criterion and Average Variance Extracted (AVE). While the reliability test is measured using Composite Reliability and Cronbach's Alpha. While testing the hypothesis using test $\mathrm{f}^{2}$, test $\mathrm{R}^{2}$, and $\mathrm{t}$-test.

\section{Results}

\subsection{Validity Test}

The results of the Smart PLS 3.0 software output obtained Fornell-Lacker Criteri on value and AVE (Average Variance Extracted) value for each variable are as follows:

Table 1 Validity Test Results

\begin{tabular}{lcc}
\hline & Fornell Lacker-Criterion & Average Variance Extracted (AVE) \\
\hline Financial Literacy & 0.708 & 0.501 \\
Financial Technology & 0.848 & 0.720 \\
Income & 0.798 & 0.637 \\
Locus of Control & 0.738 & 0.545 \\
Financial Behavior & 0.749 & 0.562 \\
\hline
\end{tabular}

Source: Smart PLS 3.0 Output

Table 1 shows the results of the validity test. Lacker Fornell-Criterion value should be higher than the value of $\mathrm{R}^{2}$ and AVE values should be above 0.5 so that it 
can be said to be valid (Sujarweni, 2015). The value of R2 nature of this study was 0.697 , so it can be said that the variables of financial literacy, financial technology, revenue, locus of control, and financial behavior are valid.

\subsection{Reliability Test}

The results of the Smart PLS 3.0 software output obtained the value of Composite Reliability and Cronbach's Alpha for each variable are as follows:

Table 2 Reliability Test Results

\begin{tabular}{lcc}
\hline & Composite Reliability & Cronbach's Alpha \\
\hline Financial Literacy & 0.899 & 0.874 \\
Financial Technology & 0.926 & 0.899 \\
Income & 0.837 & 0.704 \\
Locus of Control & 0.890 & 0.904 \\
Financial Behavior & 0.911 & 0.888 \\
\hline
\end{tabular}

Source: Smart PLS 3.0 Output

Table 2 shows the results of the reliability test. Composite Reliability value must be above 0.6 and Cronbach's Alpha value must be above 0.7 in order to be said to be reliable (Sujarweni, 2015). Therefore, seen from the reliability test results, it can be said that the variables of financial literacy, financial technology, income, locus of control, and financial behavior have good reliability.

\section{3 $\mathrm{F}^{2}$ Test}

Following are the results of $\mathrm{f}^{2}$ using Smart PLS 3.0 as follows:

Table 3 Value of $\mathbf{f}^{2}$

\begin{tabular}{lc}
\hline & Financial Behavior (Y) \\
\hline Financial Technology (X2) & 0.031 \\
Financial Literacy (X1) & 1.420 \\
Income (X3) & 0.114 \\
Locus Of Control & 0.013 \\
\hline \multicolumn{2}{c}{ Source: Smart PLS 3.0 Output }
\end{tabular}

Table 8 shows that financial technology has a weak influence on financial behavior that is equal to 0.031 or $3.1 \%$. Financial literacy has a strong influence on financial behavior that is equal to 1.420 , or $142 \%$. Income has an influence which is weak against financial behavior that is equal to 0.114 or $11.4 \%$ Locus of control has a weak influence on financial behavior that is equal to 0.013 or $1.3 \%$.

\section{4 $\mathrm{R}^{2}$ Test}

This test is used to find out how much the ability of all independent variables $(\mathrm{X})$ in explaining the variance of the dependent variable $(\mathrm{Y})$. Here are the results of $\mathrm{R}^{2}$ based on the output using the Smart PLS 3.0:

\section{Table $4 \mathbf{R}^{2}$ dan $\mathbf{R}^{2}$ Adjusted Values}

\begin{tabular}{ccc}
\hline & R-Square & R-Square Adjusted \\
\hline Financial Behavior & 0.713 & 0.697 \\
\hline & Source: Smart PLS 3.0 Output
\end{tabular}

According to the table 9, it can be seen that the magnitude of R-Square Adjusted of finance behavior amounted to 0.697 which means that the effect of financial technology, financial literacy, income, and locus of control on the financial behavior is strong that is equal to 0.697 or $69.7 \%$ and $30.3 \%$ influenced by other variables outside of this study. 


\subsection{T-Test}

Following are the t-statistic results obtained after analysis using Smart PLS 3.0:

Table 5 T-Test Results

\begin{tabular}{lcccc}
\hline & & $\begin{array}{c}\text { Original } \\
\text { Sample (O) }\end{array}$ & $\begin{array}{c}\text { T Statistic } \\
(|\mathbf{O} / \mathbf{S T D E V}|)\end{array}$ & P Values \\
\hline Financial Technology $\quad->\quad$ Financial & 0.099 & 1.525 & 0.128 \\
Behavior & 0.702 & 10.435 & 0.000 \\
Financial Literacy -> Financial Behavior & 0.201 & 2.942 & 0.003 \\
Income -> Financial Behavior & -0.061 & 0.677 & 0.499 \\
Locus Of Control -> Financial Behavior &
\end{tabular}

\section{Source: Smart PLS 3.0 Output}

The Original Sample value is used to determine whether the effect of the independent variable on the dependent variable is positive or negative. The value of tstatistic is used to determine whether the independent variable influences the dependent variable, with the terms t-statistic $>\mathrm{t}$-table so that it can be said to be influential. The value of $P$ Values is used to measure the level of significance of the influence of the independent variables on the dependent variable, with a significant requirement that is $\mathrm{P}$ Values $<0.05$.

This study uses four independent variables, one dependent variable and 80 respondents so it gets a t-table value of 1.99210 . So the results of this hypothesis test are that financial literacy has a significant positive effect on financial behavior, financial technology does not affect financial behavior, income has a significant positive effect on financial behavior, and locus of control has no effect on financial behavior.

\section{Discussion}

\subsection{Effect of Financial Literacy on Financial Behavior}

Based on hypothesis testing that has been done, it shows that the level of financial knowledge of a person can influence the way that person makes financial decisions. From the results of this study, it can be seen that the majority of Lecturers in the Faculty of Economics and Business at the UPN Veteran Jakarta have general personal financial knowledge, savings and loans, investments, and insurance that are quite good. Therefore, in this study, it can be said that more higher level of lecturer financial literacy, it will create better lecturers' financial behavior. It can be said if a lecturer has a low level of financial literacy, it will face financial problems in his life because financial literacy plays an important role in fixing someone's behavior. Moreover, a majority of lecturers are married, their needs are very diverse and must be met with income that may be limited, so financial literacy is needed to form good financial behavior to avoid financial difficulties and to achieve financial prosperity in his life.

The results of this study are consistent with research conducted by Mien and Thao (2015), Erawati and Susanti (2017), Anggraeni, and Tandika (2019), and Herawati (2015) who state that financial knowledge influences financial behavior.

\subsection{Effect of Financial Technology on Financial Behavior}

Based on the hypothesis testing that has been done, it shows that one's understanding of financial technology services and products and the use of financial technology does not affect the person's financial behavior. This is caused by the understanding and use of financial technology by the Lecturer of the Faculty of Economics and Business, UPN Veteran Jakarta, which is not yet optimal. The presence of financial technology has a negative and positive impact. The impact that is generally obtained by the presence of fintech is that it becomes easier for someone to access various financial services and products, which can be in the form of ease of transaction, saving, investing, and making loans. The positive impact obtained is that someone can 
easily save and invest because it can be accessed only with a smartphone and at a more affordable cost. While the negative impact is that with the convenience provided in the field of payment, a person can be consumptive because they can easily spend money because they do not feel they are spending money physically.

This indicates that someone must also have the good financial literacy to avoid irresponsible financial behavior. Therefore, the Otoritas Jasa Keuangan (OJK) in collaboration with various financial institutions, and the government continues to encourage the level of financial literacy of the Indonesian people to avoid bad financial behavior.

\subsection{Effect of Income on Financial Behavior}

Based on the hypothesis test that has been done, states that income affects financial behavior. The salary received by the majority of Lecturers in the Faculty of Economics and Business, UPN Veteran Jakarta has been in accordance with the work done and is sufficient to meet their daily needs for one month. The majority of income received by the Lecturers at the Faculty of Economics and Business, UPN Veteran Jakarta, ranges from Rp 6,000,000 to Rp 9,999,999. From the above data, it can be said that many of the Lecturers at the Faculty of Economics and Business at the UPN Veteran Jakarta have high incomes and this affects their financial management. Low, moderate, and high income owned by someone has a difference in the financial behavior of that person. In other words, the higher a person's income level, the better the person's financial behavior. It can be said that a lecturer who has a higher income will have the opportunity to behave more responsibly financially than a lecturer who has a lower income so that lecturers with a higher income can behave better financially than a lecturer who has a lower income. Likewise, a higher income can provide an opportunity for someone to save or invest because the possibility is still a surplus from his income.

The results of this study are consistent with research conducted by Andrew and Linawati (2014) and Zakaria, Noor Jaafar, and Marican (2012) which state that income influences financial behavior.

\subsection{Effect of Locus of Control on Financial Behavior}

Based on the hypothesis test that has been done, shows that the locus of control does not affect financial behavior. This can be interpreted that the good or bad locus of control at the Lecturer of the Faculty of Economics and Business UPN Veteran Jakarta does not affect the financial behavior of the lecturer. It can also be interpreted in the locus of control indicators such as orientation towards potential behavior, expectations, the value of reinforcing elements, and psychological arrangements that do not affect financial behavior.

The results of this study are consistent with research conducted by Mien and Thao (2015) which states that people who have a more external locus of control lead to worse financial behavior. External Locus of control has a negative effect on financial behavior. However, the results of this study are inversely proportional to the research conducted by Yusnia and Jubaedah (2017) and Kholihah and Iramani (2013) who concluded that the locus of control variable had a significant influence on financial behavior.

\section{Conclusion}

Based on the results of research and hypothesis testing that has been done through PLS (Partial Least Square) analysis in the previous discussion, the following conclusions can be drawn:

a. Financial literation effect on the financial behavior of the Lecturer at the Faculty of Economics and Business, Universitas Pembangunan Nasional Veteran Jakarta. 
b. Financial technology does not affect the financial behavior of the Lecturer at the Faculty of Economics and Business, Universitas Pembangunan Nasional Veteran Jakarta.

c. Income effect on the financial behavior of Lecturer at the Faculty of Economics and Business, Universitas Pembangunan Nasional Veteran Jakarta.

d. Locus of Control does not affect the financial behavior of the Lecturer at the Faculty of Economics and Business, Universitas Pembangunan Nasional Veteran Jakarta.

\section{References}

Alexander, R., \& Pamungkas, A. S. (2019). Effects of Financial Knowledge, Control Locations, and Revenue on Financial Behavior. Managerial and Entrepreneurship Journal, 1 (1).

Amalini, H. F., et al. (2016). Effect of Locus of Control on Job Satisfaction and Performance, 35 (1) 68-77.

Andrew, V., \& Linawati, N. (2014). The Relationship between Demographic Factors and Financial Knowledge with the Financial Behavior of Private Employees in Surabaya. FINESTA, 02 (02), 35-39.

Anggraeni, A. A., \& Tandika, D. (2019). Effects of Financial Literacy and Financial Attitude on Financial Management Behavior. Proceedings of Management, 5 (1). ISSN: 2460-6545.

Bank Indonesia. (2016). Bank Indonesia Regulation Number 18/40/PBI/2016 concerning the Implementation of Payment Transaction Processing. Jakarta: Bank Indonesia.

Bank Indonesia. (2016). Bank Indonesia Regulation Number 18/40/PBI/2016 concerning the Implementation of Payment Transaction Processing. Jakarta: Bank Indonesia.

Bank Indonesia. (2017). Bank Indonesia Regulation Number 19/12/PBI/2017 concerning Implementation of Financial Technology. Jakarta: Bank Indonesia.

Burcher, S. A., et al. (2018). Using the Expectancy-Value Theory to Understand Emerging Adult's Financial Behavior and Financial Well-Being. Society for the Study od Emerging Adulthood and SAGE Publishing.

Erawati, N., \& Susanti. (2017). Effect of Financial Literacy, Learning in Higher Education, and Work Experience on Student Financial Behavior at the Faculty of Economics, State University of Surabaya.

Herawati, N. T. (2015). Contribution of Learning in Higher Education and Financial Literacy to Student Financial Behavior. Journal of Education and Teaching, 48 (1-3), 60-70.

Herdjiono, I., \& Damanik, L. A. (2016). Effects of Financial Attitude, Financial Knowledge, Parental Income on Financial Management Behavior. Journal of Theory and Applied Management, 227-230.

Ida., \& Dwinta, C. Y. (2010). The Effect of Locus of Control, Financial Knowledge, Income on Financial Behavior Management. Journal of Business and Accounting, 12 (3), 131-144. 
Kholihah, N. A., \& Iramani R. (2013). Study of Financial Management Behavior in Surabaya Society. Journal of Business and Banking, 3 (1), 69-80.

Larasati, S. (2018). Human Resource Management. Yogyakarta: Deepublish.

Mien, N. T., \& Thao, T. P. (2015). Factors Affecting Personal Financial Management Behaviors: Evidence from Vietnam. Proceedings of the Second Asia-Pacific Conference on Global Business, Economics, Finance, and Social Sciences, ISBN: 978-1-63415-833-6.

Otoritas Jasa Keuangan. (2016). Copies of Otoritas Jasa Keuangan Regulation Number 76/POJK.07/2016 concerning Improvement of Financial Literacy and Financial Inclusion in the Financial Services Sector for Consumers and/or the Community. Jakarta: Otoritas Jasa Keuangan.

Otoritas Jasa Keuangan. (2016). National Literacy and Financial Inclusion Survey 2016. Jakarta: Otoritas Jasa Keuangan.

Pradiningtyas, T. E., \& Lukiastuti, F. (2019). Effect of Financial Knowledge and Financial Attitudes on Locus of Control and Behavior of Financial Management of Student Economics. Journal of Minds: Management of Ideas and Inspiration, $6(1)$.

Purwidianti, W., \& Mudjiyanti, R. (2016). Analysis of the Effects of Financial Experience and Income Levels on Family Financial Behavior in Purwokerto Timur District. BENEFIT Journal of Management and Business, I, 141-142.

Subandriyo. (2016). Effect of Government Policy on Cocoa Farmer Income in Jayapura Regency. YogyAkarta: Deepublish.

Sujarweni, V. W. (2015). Research Methodology - Business \& Economics. Yogyakarta: New Library Press.

Suryanto. (2017). Student Financial Behavior Patterns in Higher Education. Journal of Political Science and Communication, VII, 11-15.

Wibowo. (2013). Behavior in Organizations. Jakarta: PT Raja Grafindo Persada.

Yusnia., \& Jubaedah. (2017). Effect of Income, Control Locations, and Financial Knowledge on the Financial Behavior of Cinere District SMEs. Journal of Economics and Business UPNVJ, 4 (2).

Zakaria, R. Z., et al. (2012). Financial Behavior and Financial Position: a Structural Equation Modeling Approach. The Middle East. Journal of Scientific Research, $11(5), 1-16$. 